Annals of Warsaw University of Life Sciences - SGGW

Land Reclamation No 48 (1), 2016: 79-94

(Ann. Warsaw Univ. Life Sci. - SGGW, Land Reclam. 48 (1), 2016)

\title{
Influence of fly-ashes on properties of ordinary concretes
}

\author{
GABRIELA RUTKOWSKA, KRZYSZTOF WIŚNIEWSKI, \\ MAREK CHALECKI, MIROSŁAWA GÓRECKA, KAMIL MIŁOSEK \\ Department of Civil Engineering, Warsaw University of Life Sciences - SGGW
}

\begin{abstract}
Influence of fly-ashes on properties of ordinary concretes. Care of the environment in accordance with the principles of sustainable development introduces the possibility and need for waste recycling. The construction and building materials industry has the greatest potential for reuse of waste. The article presents the results of investigations of selected properties (consistency, water absorbability, compressive strength and tensile strength after 28 and 56 days of curing, depth of penetration) of ordinary concretes and concretes containing fly-ashes - calcareous and siliceous ash - in their composition. To make the samples, the Portland cement CEM I $42.5 \mathrm{R}$ and natural aggregate with graining of $0-16 \mathrm{~mm}$ were used. The concrete with siliceous and calcareous admixtures was made in three lots where the ash was added in the quantity of 15,20 and $30 \%$ of the cement mass. After the tests, it was stated that the fly-ash admixture does not increase the air content in the mix, it increases the compressive strength in time and the siliceous ash improves the splitting tensile strength.
\end{abstract}

Key words: industrial waste, fly-ash, concrete, concrete with admixtures

\section{INTRODUCTION}

The perspective of depletion of mineral fuels and the care of environment influenced the determination of strategic goals for the states - members of European Union for the oncoming years in a framework of the strategy "Europe 2020". Innovative solutions are being introduced, encompassing i.a. the energetic sector. Nowadays, the global power industry seeks for alternative sources of renewable energy. Apart of the conventional fuels, like brown and bituminous coal (Deja and Antosiak 2012), successful attempts of biomass combustion or co-combustion are being observed (Golec et al. 2007, Rutkowska and Małuszyńska 2014). The combustion by-products arising as a result of combustion in a professional power industry were recycled by disposal on the earth surface or underground in mines (Koda and Osiński 2011). This form of ash recycling results in degradation of surface and underground water due to the penetration of components from the wastes in the area of their disposal (Rosik-Dulewska and Karwaczyńska 2008). Hence the investigations are necessary which would encompass i.a. the evaluation of possibilities of application of fly-ashes in the material recycling used in the building industry. This evaluation is the topic of this paper.

The idea of application of fly-ash in the ordinary concrete production is not new. Fly-ashes were applied as first in the USA in the 1930s (Wesche 1991, 
Malhotra and Ramezanianpour 1994, ACI Committee 1996, Joshi and Lohtia 1997, Comões 2002). In Poland and Europe, the siliceous fly-ashes coming from the combustion of bituminous coal have wide application in the cement technology, mainly in the concrete technology (Giergiczny 2006, Giergiczny 2013). Present among the ingredients of cement and concrete, the fly-ashes cause that the quantity of the cement clinker and aggregates needed in the concrete production is lower. In consequence, it evokes savings of natural materials and mineral fuels as well as reduction of the environment pollution and emission of carbon dioxide (Deja and Antosiak 2012). The wide application of the fly-ash in the building industry is mainly due to: its high fineness, close to this of the cement, its chemical constitution and phase composition as well as its reactivity, particularly the pozzolanic activity. At the same time, the fly-ash has the positive influence on some features of the concrete (Lai and Serra 1997, Kim and Kim 2002, Gupta 2007). These factors cause that the production of fly-ash concretes is attractive both for producers and for final consumers.

The paper presents the results of investigations which were aimed to analyze how the siliceous and calcareous fly-ashes added to an ordinary concrete mix influence the technical properties of the mix.

Possibilities and scope of application of the fly-ashes in the concrete production are defined by the stand- ards: PN-EN 206-1:2003, PN-EN 450-1+A1:2009, PN-EN 197-1:2002/ /A3:2007, PN-EN 450-2.

\section{MATERIAL AND METHODS}

\section{Methodology}

The research and design procedures are based on the directives contained in the currently binding Polish building standards. The tests were performed in the Laboratory of Building Constructions of the Department of Civil Engineering as well as in the Laboratory of Physical Processes in Building in the Water Center of the Faculty of Civil and Environmental Engineering of Warsaw University of Life Sciences (WULS).

The concrete for the samples being tested was calculated as ordinary concrete according to the standard PN-EN-206-1:2003. To perform the tests, C20/25 concrete mixes with the F2 type consistency (viscoplastic) were prepared. The mix composition was calculated with the use of the method of three equations according Kluz-Eyman. To prepare the concrete samples, ordinary aggregate with the graining $0.125-16$ $\mathrm{mm}$ and Portland cement without admixtures were used.

The consistency of the concrete mixes was tested with the concrete slump test according to the standard PN-EN 12350-2:2009. To investigate the compression strength, the samples of the size $100 \times 100 \times 100 \mathrm{~mm}$ were used. The investigations were performed according to the directives contained in the stand- 
ard PN-EN 12390-3:2009. The samples were subjected to the tests after 28 days of the concrete curing period. To investigate the splitting tensile strength, the samples of the size $150 \times 150 \times 150 \mathrm{~mm}$ were used. The investigations were performed according to the directives contained in the standard PN-EN 12390-6:2009. The water penetration depth was tested according to the directives contained in the standard PN-88/B-0650.

\section{Fly-ashes for concretes}

Grains of fly-ash have the diameter from 1 to $150 \mu \mathrm{m}$ - it is close to the cement grain diameter falling into the range 7-12 $\mu \mathrm{m}$ (Joshi and Lohtia 1997). They usually have a spheroid shape, but they can also be prismatic and irregular. They contain ca. $80 \%$ of glass and are characterized by high fineness. The Blaine specific surface is equal $250-550 \mathrm{~m}^{2} / \mathrm{kg}$ (Alonso and Wesche 1991). According to Malhotra and Ramezanianpour (1994), the graining and the surface of the fly-ash is not connected to its source. The grains bigger than $125 \mu \mathrm{m}$ have high porosity. It is due to the higher share of coal. High content of coal affects the concrete freeze resistance (the higher content of coal, the lower freeze resistance) as well as increases the water demand [Alonso and Wesche 1991].

Taking the chemical properties into consideration, the fly-ashes contain mostly silica, $\mathrm{Al}_{2} \mathrm{O}_{3}, \mathrm{Fe}_{2} \mathrm{O}_{3}$ and $\mathrm{CaO}$. There is significantly less $\mathrm{MgO}, \mathrm{Na}_{2} \mathrm{O}$,
$\mathrm{SO}_{3}$ (ACI Committee 1996, Malhotra and Ramezanianpour). The content of the main ingredients fluctuates but their share complies with the standard and it falls into the ranges: $\mathrm{SiO}_{2}-35-60 \%$, $\mathrm{Al}_{2} \mathrm{O}_{3}-10-30 \%, \mathrm{Fe}_{2} \mathrm{O}_{3}-4-20 \%$ and $\mathrm{CaO}-1-35 \%$ (ACI Committee 1996).

According to Alonso and Wesche (1991), the pozzolanic activity of the fly-ashes depends on the silica content, however, according to Camões, the reduction of this content does not worsen the properties of concrete mix and hardened concrete (Camões 2002, Martins and Camões 2013).

The fly-ash, applied in the investigations, is a very fine ash with hydraulic and pozzolanic properties. The main ingredients are: reactive calcium oxide $(\mathrm{CaO})$, reactive silicon dioxide $\left(\mathrm{SiO}_{2}\right)$ and aluminum oxide $\left(\mathrm{Al}_{2} \mathrm{O}_{3}\right)$. Table 1 shows the composition of fly-ashes used in the investigations.

TABLE 1. Chemical composition of fly-ash (Investigation report 721/2014]

\begin{tabular}{|l|c|c|}
\hline Contents & $\begin{array}{c}\text { Calcareous } \\
\text { fly-ash } \\
\text { [\% of mass] }\end{array}$ & $\begin{array}{c}\text { Siliceous } \\
\text { fly-ash } \\
\text { [\% of mass] }\end{array}$ \\
\hline $\begin{array}{l}\text { Loss on } \\
\text { ignition }\end{array}$ & 2.1 & 8.26 \\
\hline $\mathrm{SiO}_{2}$ & 42.8 & 49.3 \\
\hline $\mathrm{Al}_{2} \mathrm{O}_{3}$ & 20.5 & 27.8 \\
\hline $\mathrm{Fe}$ & 4.4 & 5.21 \\
\hline $\mathrm{CaO}$ & 22.5 & 2.03 \\
\hline $\mathrm{MgO}$ & 0.9 & 1.57 \\
\hline $\mathrm{SO}$ & 4.3 & 0.43 \\
\hline $\mathrm{Na}_{2} \mathrm{O}$ & 0.1 & 0.57 \\
\hline $\mathrm{K}_{2} \mathrm{O}$ & 0.2 & 2.45 \\
\hline $\mathrm{CaO}$ free & 4.1 & - \\
\hline
\end{tabular}




\section{Laboratory tests}

To make the samples, first type Portland cement without admixtures was used (Cement Plant "Odra" S.A., Opole, Poland). The fly-ashes used for the fly-ash concrete samples came from two thermal-electric power stations: Siekierki (Warsaw) and Bełchatów; they complied with the requirements given in the standard PN-EN 450-1+A1:2009 on the requirements for the fly-ashes applied in the concrete production. were prepared: without any admixtures, with addition of the siliceous fly-ash, with addition of the calcareous fly-ash.

The constant grain composition of the aggregates was retained both in the samples without admixtures and in the samples with addition of the fly-ashes - the percentage content of individual fractions was determined by iterations (Fig. 1).

All of the concrete mixtures were prepared in the Laboratory of Building

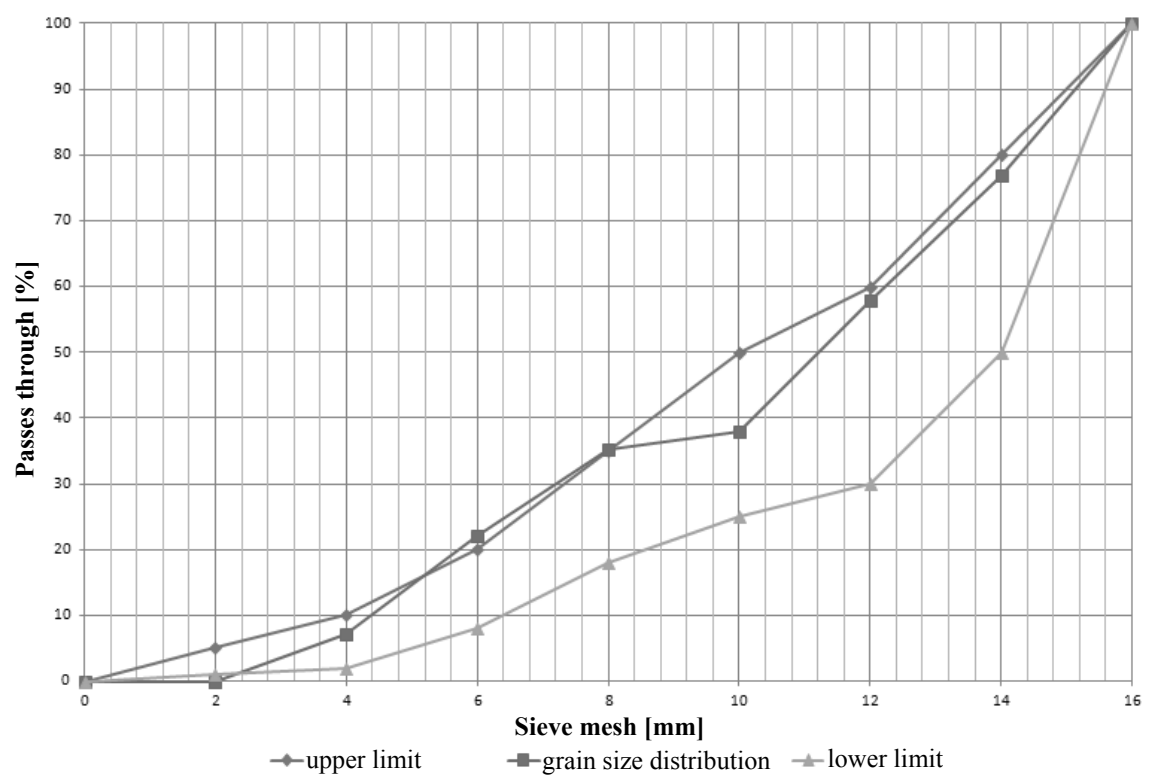

FIGURE 1. Upper and lower limit curves of grain size and grain size distribution curve of aggregate (selected by iterations)

The tests consisted in the comparison of features of ordinary concretes produced in the traditional way as well as the concretes containing the combustion by-products in form of fly-ashes of two types - siliceous and calcareous. To do this, three types of concrete samples
Constructions of the Faculty of Civil and Environmental Engineering of WULS-SGGW. During the tests the following properties of concrete mix and hardened concrete were investigated:

- consistency of concrete mix,

- density of concrete mix, 
- air content,

- concrete absorbability,

- compression and bending strength after 28 and 56 days of curing,

- splitting tensile strength.

To perform the tests, the C20/25 concrete mixes of viscoplastic consistency were designed. The quantity of ingredients of the concrete mix was calculated with the method of three equations according Kluz-Eymann [Jamroży 2005]. To prepare the concrete samples, natural aggregate with graining of $0.125-16 \mathrm{~mm}$ as well as 42.5 type Portland cement without admixtures with density of $3.1 \mathrm{~kg} / \mathrm{dm}^{3}$ and early strength R were used. Compositions of the concrete mixes for 1 $\mathrm{m}^{3}$ of batch are presented in Table 2 .

TABLE 2. Composition of the concrete mix modified with siliceous and calcareous fly-ashes

\begin{tabular}{|c|c|c|c|c|}
\hline 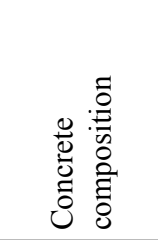 & 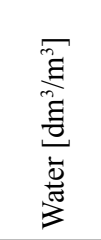 & 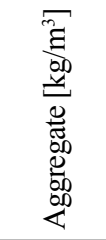 & 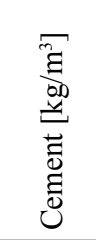 & 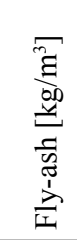 \\
\hline $\begin{array}{l}\text { Concrete } \\
\text { without } \\
\text { admixtures }\end{array}$ & 166.66 & 1899.2 & 361.66 & 0 \\
\hline $\begin{array}{l}\text { Concrete } \\
\text { with addi- } \\
\text { tion of } 15 \% \\
\text { of ash }\end{array}$ & 166.66 & 1899.2 & 307.41 & 54.25 \\
\hline $\begin{array}{l}\text { Concrete } \\
\text { with addi- } \\
\text { tion of } 20 \% \\
\text { of ash }\end{array}$ & 166.66 & 1899.2 & 289.33 & 72.33 \\
\hline $\begin{array}{l}\text { Concrete } \\
\text { with addi- } \\
\text { tion of } 30 \% \\
\text { of ash }\end{array}$ & 166.66 & 1899.2 & 253.16 & 108.5 \\
\hline
\end{tabular}

After establishing a recipe the concrete mixes were produced and laboratory tests were performed.

\section{RESULTS OF THE CONCRETE MIX TESTS}

\section{Concrete mix density test}

The density of the concrete mix without ash admixtures was equal $2.365 \mathrm{~kg} / \mathrm{dm}^{3}$ and was slightly lower than the density of the mix with the $20 \%$ of siliceous and calcareous ash content, which was equal $2.369 \mathrm{~kg} / \mathrm{dm}^{3}$ for the both cases (Fig. 2). The lowest value was obtained for the mix with the $15 \%$ of siliceous ash content - it was equal $2.316 \mathrm{~kg} / \mathrm{dm}^{3}$; for the calcareous ash of the same content, the obtained value was equal $2.351 \mathrm{~kg} / \mathrm{dm}^{3}$. The density of the concrete mix with the $30 \%$ of calcareous ash content was equal $2.331 \mathrm{~kg} / \mathrm{dm}^{3}$, however, for the siliceous ash content $-2.337 \mathrm{~kg} / \mathrm{dm}^{3}$.

\section{Air content}

Figure 3 shows the results of the performed tests of air content in concrete mix.

The concrete mix without ash admixture showed the lowest air content equal $2.4 \%$. Along with the increase of ash content in the mix, the increase of the air content was observed. It was equal $2.9 \%$ for the concrete mix with the $15 \%$ of siliceous ash content and $2.7 \%-$ calcareous ash content. The mixes with the $20 \%$ of siliceous and calcareous ash content reached 3.2 and $3 \%$ of the air 


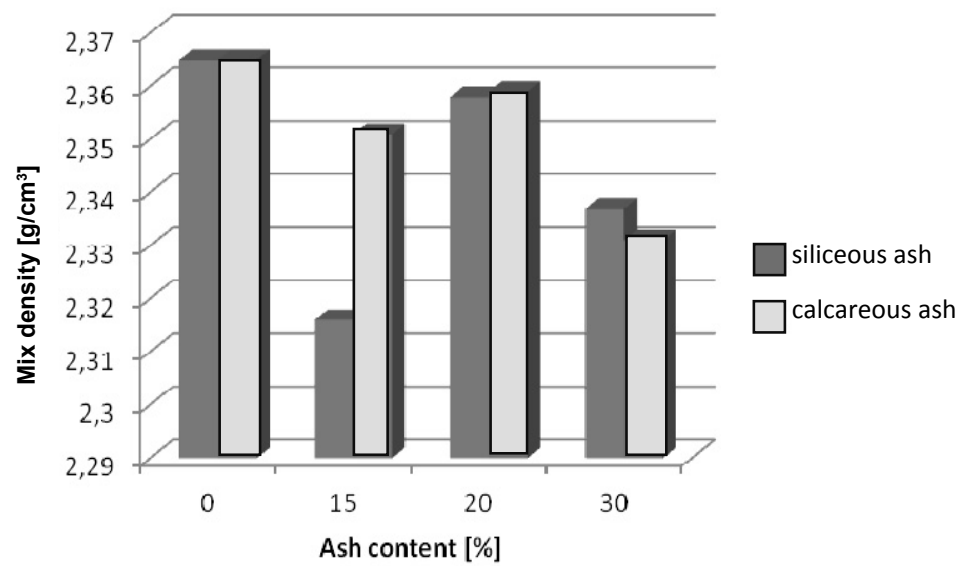

FIGURE 2. Density of the concrete mix depending on the fly-ash percentage content

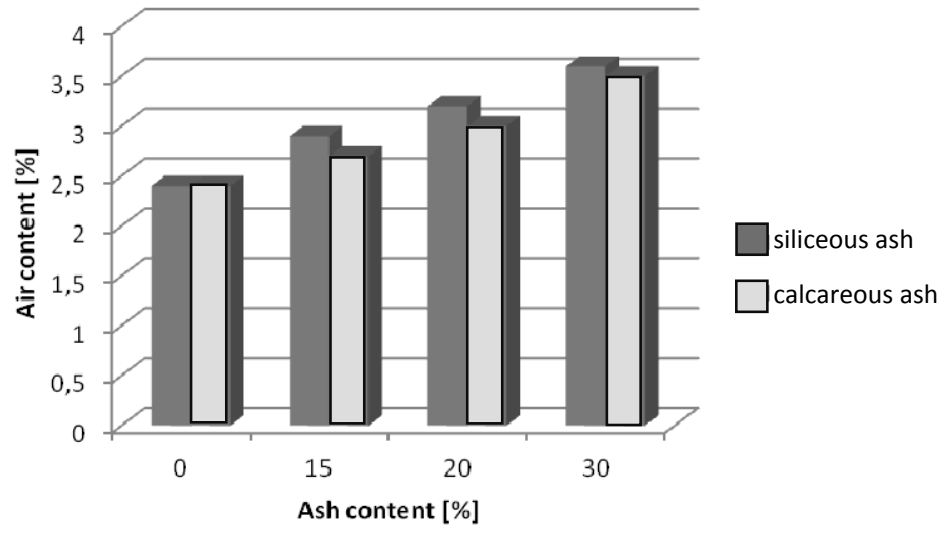

FIGURE 3. The air content depending on the ash content

content, respectively. The mix with the $30 \%$ of siliceous ash content contained $3.6 \%$ of air, however with the calcareous ash $-3.6 \%$ of air.

\section{Consistency tests: slump test and Vebe test}

Table 3 presents the results of the consistency test performed with the concrete slump test as well as the consistency class obtained in the test.
The concrete mixes were characterized by small and very similar slump and all of them were qualified as belonging to the $\mathrm{S} 1$ consistency class. It could be observed in the Vebe test that the measured time decreased along with the increase of the siliceous ash content whereas it increased along with the increase of the calcareous ash content. According to the Vebe test, the mix with the 20 and $30 \%$ of calcareous ash content was qualified 
TABLE 3. The obtained consistency class

\begin{tabular}{|l|c|c|}
\hline Type of concrete mix & $\begin{array}{c}\text { Slump } \\
\text { test } \\
\text { [cm] }\end{array}$ & $\begin{array}{c}\text { Obtained } \\
\text { consistency } \\
\text { class }\end{array}$ \\
\hline $\begin{array}{l}\text { Mix without } \\
\text { admixtures }\end{array}$ & 1 & $\mathrm{~S} 1$ \\
\hline $\begin{array}{l}\text { Mix with } 15 \% \text { of } \\
\text { siliceous ash content }\end{array}$ & 1.2 & $\mathrm{~S} 1$ \\
\hline $\begin{array}{l}\text { Mix with } 20 \% \text { of } \\
\text { siliceous ash content }\end{array}$ & 1.3 & $\mathrm{~S} 1$ \\
\hline $\begin{array}{l}\text { Mix with } 30 \% \text { of } \\
\text { siliceous ash content }\end{array}$ & 2.2 & $\mathrm{~S} 1$ \\
\hline $\begin{array}{l}\text { Mix with } 15 \% \text { of } \\
\text { calcareous ash content }\end{array}$ & 1.2 & $\mathrm{~S} 1$ \\
\hline $\begin{array}{l}\text { Mix with } 20 \% \text { of } \\
\text { calcareous ash content }\end{array}$ & 1.6 & $\mathrm{~S} 1$ \\
\hline $\begin{array}{l}\text { Mix with } 30 \% \text { of } \\
\text { calcareous ash content }\end{array}$ & 1.9 & $\mathrm{~S} 1$ \\
\hline
\end{tabular}

as belonging to the $\mathrm{V} 2$ consistency class, whereas the remaining mixes - V3 consistency class.

\section{RESULTS OF THE HARDENED CONCRETE TESTS}

\section{Compressive strength test}

Tables 4-5 and Figures 4-5 present the results of the compressive strength tests for concrete samples of a cubic form with the size of $100 \times 100 \times 100 \mathrm{~mm}$. The tests were performed after 28 and 56 days of concrete curing.

TABLE 4. The results of the compressive strength tests after 28 days

\begin{tabular}{|c|c|c|c|c|c|c|c|c|}
\hline $\begin{array}{l}\text { Concrete } \\
\text { type }\end{array}$ & $\begin{array}{l}\text { Num- } \\
\text { ber }\end{array}$ & $\begin{array}{c}\text { Mass } \\
{[\mathrm{g}]}\end{array}$ & \multicolumn{3}{|c|}{$\begin{array}{l}\text { Dimensions } \\
{[\mathrm{mm}]}\end{array}$} & $\begin{array}{l}\text { Force } \\
{[\mathrm{kN}]}\end{array}$ & $\begin{array}{c}\text { Strength } \\
{[\mathrm{MPa}]}\end{array}$ & $\begin{array}{c}\text { Corrected } \\
\text { average } \\
\text { strength }\end{array}$ \\
\hline \multirow{3}{*}{$\begin{array}{l}\text { Concrete without } \\
\text { admixtures }\end{array}$} & 1 & 2.443 & 101.37 & 100.77 & 101.04 & 540.1 & 52.8 & \multirow{3}{*}{50.7} \\
\hline & 2 & 2.389 & 100.05 & 100.13 & 101.40 & 541.9 & 54.0 & \\
\hline & 3 & 2.394 & 100.25 & 99.80 & 100.49 & 532.7 & 53.2 & \\
\hline \multirow{3}{*}{$\begin{array}{l}\text { Concrete with } \\
15 \% \text { of siliceous } \\
\text { ash content }\end{array}$} & 1 & 2.305 & 100.44 & 100.47 & 100.41 & 382.2 & 37.8 & \multirow{3}{*}{35.6} \\
\hline & 2 & 2.351 & 100.60 & 100.29 & 101.47 & 372.1 & 36.5 & \\
\hline & 3 & 2.307 & 100.42 & 100.53 & 101.65 & 384.9 & 38.1 & \\
\hline \multirow{3}{*}{$\begin{array}{l}\text { Concrete with } \\
20 \% \text { of siliceous } \\
\text { ash content }\end{array}$} & 1 & 2.317 & 100.87 & 101.67 & 100.27 & 373.5 & 36.4 & \multirow{3}{*}{34.8} \\
\hline & 2 & 2.323 & 100.64 & 99.74 & 100.71 & 363.8 & 35.4 & \\
\hline & 3 & 2.348 & 101.40 & 100.36 & 100.93 & 389.4 & 38.1 & \\
\hline \multirow{3}{*}{$\begin{array}{l}\text { Concrete with } \\
30 \% \text { of siliceous } \\
\text { ash content }\end{array}$} & 1 & 2.297 & 100.96 & 100.86 & 100.57 & 344.9 & 33.8 & \multirow{3}{*}{31.4} \\
\hline & 2 & 2.274 & 101.77 & 100.52 & 100.39 & 355.9 & 34.7 & \\
\hline & 3 & 2.284 & 100.28 & 101.40 & 100.55 & 312.8 & 30.7 & \\
\hline \multirow{3}{*}{$\begin{array}{l}\text { Concrete with } \\
15 \% \text { of calcare- } \\
\text { ous ash content }\end{array}$} & 1 & 2.392 & 100.29 & 101.02 & 101.81 & 502.2 & 49.5 & \multirow{3}{*}{45.7} \\
\hline & 2 & 2.378 & 101.58 & 100.60 & 100.56 & 512.5 & 49.6 & \\
\hline & 3 & 2.376 & 100.60 & 100.71 & 100.80 & 463 & 45.2 & \\
\hline \multirow{3}{*}{$\begin{array}{l}\text { Concrete with } \\
20 \% \text { of calcare- } \\
\text { ous ash content }\end{array}$} & 1 & 2.338 & 101.29 & 100.35 & 100.31 & 465.1 & 45.7 & \multirow{3}{*}{41.4} \\
\hline & 2 & 2.358 & 100.85 & 100.56 & 101.13 & 398.2 & 39.2 & \\
\hline & 3 & 2.358 & 101.24 & 100.51 & 101.74 & 465.3 & 45.7 & \\
\hline \multirow{3}{*}{$\begin{array}{l}\text { Concrete with } \\
30 \% \text { of calcare- } \\
\text { ous ash content }\end{array}$} & 1 & 2.355 & 101.78 & 101.39 & 101.33 & 345.4 & 33.7 & \multirow{3}{*}{34.9} \\
\hline & 2 & 2.385 & 101.35 & 100.08 & 101.70 & 392.7 & 38.7 & \\
\hline & 3 & 2.359 & 101.76 & 100.16 & 101.61 & 386.7 & 37.8 & \\
\hline
\end{tabular}

* With coefficient 0.95 according to the standard PN-EN 12390-5:2011. 
TABLE 5. The results of the compressive strength tests after 56 days

\begin{tabular}{|c|c|c|c|c|c|c|c|c|}
\hline $\begin{array}{l}\text { Concrete } \\
\text { type }\end{array}$ & $\begin{array}{c}\text { Num- } \\
\text { ber }\end{array}$ & $\begin{array}{c}\text { Mass } \\
{[\mathrm{g}]}\end{array}$ & \multicolumn{3}{|c|}{$\begin{array}{l}\text { Dimensions } \\
{[\mathrm{mm}]}\end{array}$} & $\begin{array}{l}\text { Force } \\
{[\mathrm{kN}]}\end{array}$ & $\begin{array}{c}\text { Strength } \\
{[\mathrm{MPa}]}\end{array}$ & $\begin{array}{c}\text { Corrected } \\
\text { average } \\
\text { strength }\end{array}$ \\
\hline \multirow{3}{*}{$\begin{array}{l}\text { Concrete without } \\
\text { admixtures }\end{array}$} & 1 & 2.407 & 101.07 & 100.18 & 100.61 & 575.7 & 56.8 & \multirow{3}{*}{54.6} \\
\hline & 2 & 2.370 & 99.96 & 101.09 & 100.14 & 601 & 59.4 & \\
\hline & 3 & 2.376 & 100.92 & 99.86 & 101.19 & 567.9 & 56.3 & \\
\hline \multirow{3}{*}{$\begin{array}{l}\text { Concrete with } \\
15 \% \text { of siliceous } \\
\text { ash content }\end{array}$} & 1 & 2.361 & 99.41 & 101.01 & 100.24 & 461 & 45.9 & \multirow{3}{*}{44.9} \\
\hline & 2 & 2.347 & 100.01 & 100.58 & 100.92 & 491.7 & 48.8 & \\
\hline & 3 & 2.343 & 100.28 & 99.70 & 100.37 & 470.2 & 47.0 & \\
\hline \multirow{3}{*}{$\begin{array}{l}\text { Concrete with } \\
20 \% \text { of siliceous } \\
\text { ash content }\end{array}$} & 1 & 2.366 & 100.72 & 100.80 & 101.23 & 417.6 & 41.1 & \multirow{3}{*}{40.9} \\
\hline & 2 & 2.322 & 100.51 & 101.01 & 100.92 & 430.8 & 42.4 & \\
\hline & 3 & 2.326 & 100.58 & 100.72 & 100.92 & 462.1 & 45.6 & \\
\hline \multirow{3}{*}{$\begin{array}{l}\text { Concrete with } \\
30 \% \text { of siliceous } \\
\text { ash content }\end{array}$} & 1 & 2.282 & 100.34 & 99.90 & 100.02 & 389.2 & 38.8 & \multirow{3}{*}{37.2} \\
\hline & 2 & 2.332 & 100.20 & 101.34 & 100.59 & 402.1 & 39.6 & \\
\hline & 3 & 2.298 & 100.05 & 100.90 & 100.43 & 394.9 & 39.1 & \\
\hline \multirow{3}{*}{$\begin{array}{l}\text { Concrete with } \\
15 \% \text { of calcare- } \\
\text { ous ash content }\end{array}$} & 1 & 2.388 & 100.18 & 101.28 & 100.37 & 579.2 & 53.0 & \multirow{3}{*}{51.6} \\
\hline & 2 & 2.383 & 100.53 & 99.89 & 100.76 & 537.1 & 53.4 & \\
\hline & 3 & 2.376 & 101.19 & 100.60 & 100.34 & 575.1 & 56.5 & \\
\hline \multirow{3}{*}{$\begin{array}{l}\text { Concrete with } \\
20 \% \text { of calcare- } \\
\text { ous ash content }\end{array}$} & 1 & 2.352 & 100.74 & 100.06 & 100.56 & 515.3 & 51.1 & \multirow{3}{*}{47.4} \\
\hline & 2 & 2.348 & 99.86 & 100.34 & 100.88 & 488.5 & 48.7 & \\
\hline & 3 & 2.341 & 100.38 & 100.23 & 100.84 & 501.9 & 49.8 & \\
\hline \multirow{3}{*}{$\begin{array}{l}\text { Concrete with } \\
30 \% \text { of calcare- } \\
\text { ous ash content }\end{array}$} & 1 & 2.395 & 100.33 & 101.19 & 101.68 & 392.6 & 38.6 & \multirow{3}{*}{38.5} \\
\hline & 2 & 2.400 & 100.66 & 102.84 & 101.08 & 415.2 & 41.0 & \\
\hline & 3 & 2.345 & 100.28 & 101.36 & 100.59 & 427.4 & 41.9 & \\
\hline
\end{tabular}

* With coefficient 0.95 according to the standard PN-EN 12390-5:2011.

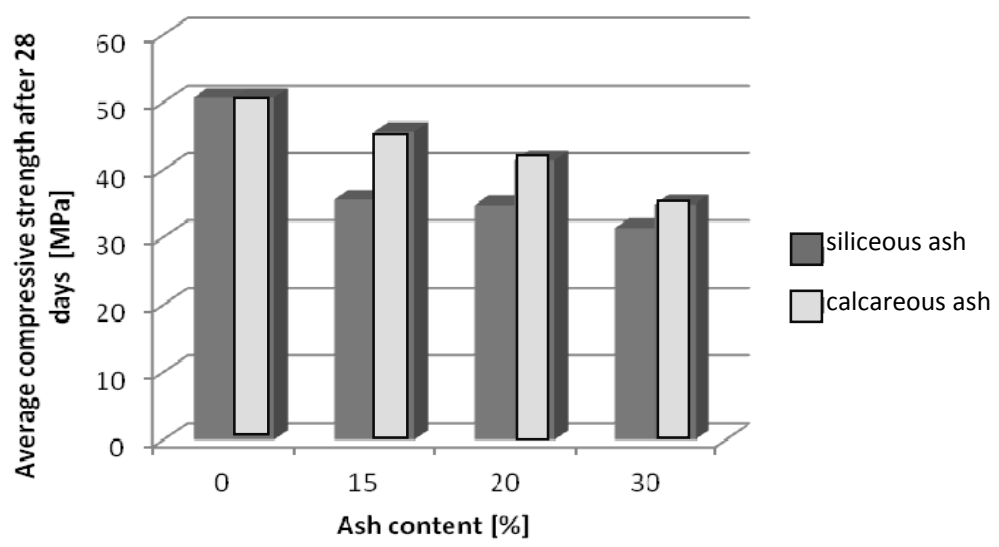

FIGURE 4. The average compressive strength after 28 days 


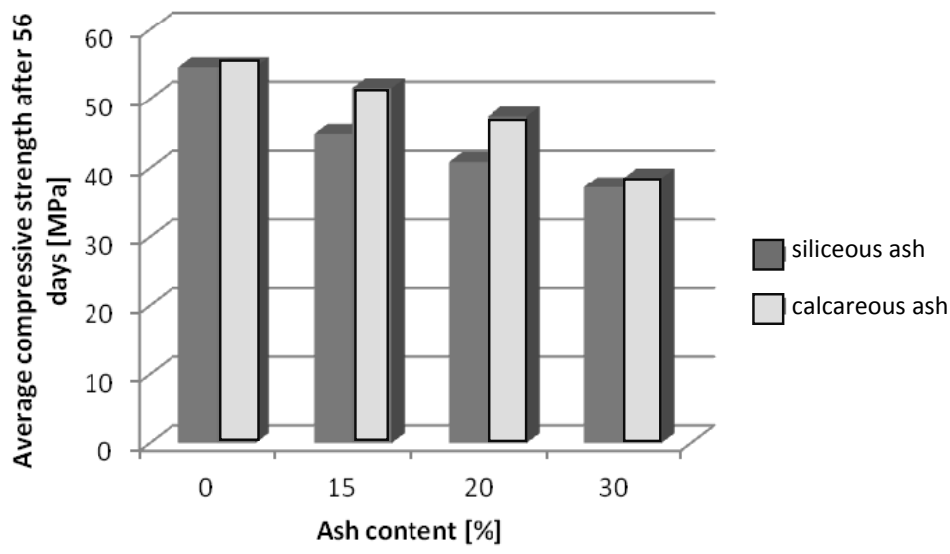

FIGURE 5. The average compressive strength after 56 days

The results obtained from the tests show (Figs 6,7) that the concrete compressive strength significantly exceeds the strength predicted during mix calculations. Each of the samples was characterized by a higher value than the assumed $25 \mathrm{MPa}$. The average compressive strength of the concrete without admixtures after 28 days of curing was equal $50.7 \mathrm{MPa}$, whereas after 56 days - 54.6.
Along with the increase of the siliceous ash content, the concrete strength decreases. For the concretes with the $15 \%$ of siliceous ash content, the average strength was equal 35.6 $\mathrm{MPa}$, however for the concrete sample with the $20 \%$ of ash content it was equal $35.6 \mathrm{MPa}$. The samples with the $30 \%$ of siliceous ash content reached significantly lower compressive strength. After 56 days

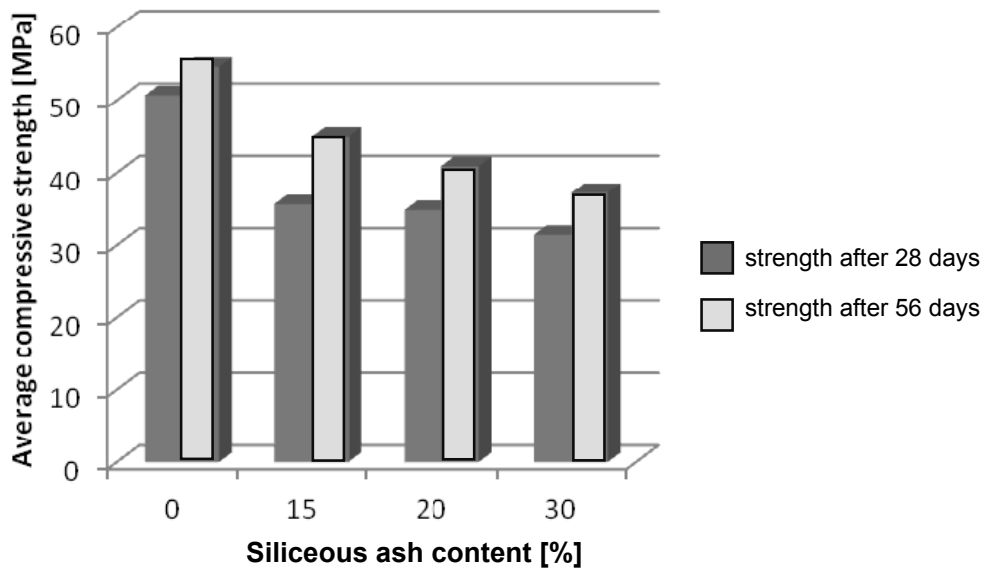

FIGURE 6. The average strength of concrete with siliceous ash after 28 and 56 days 


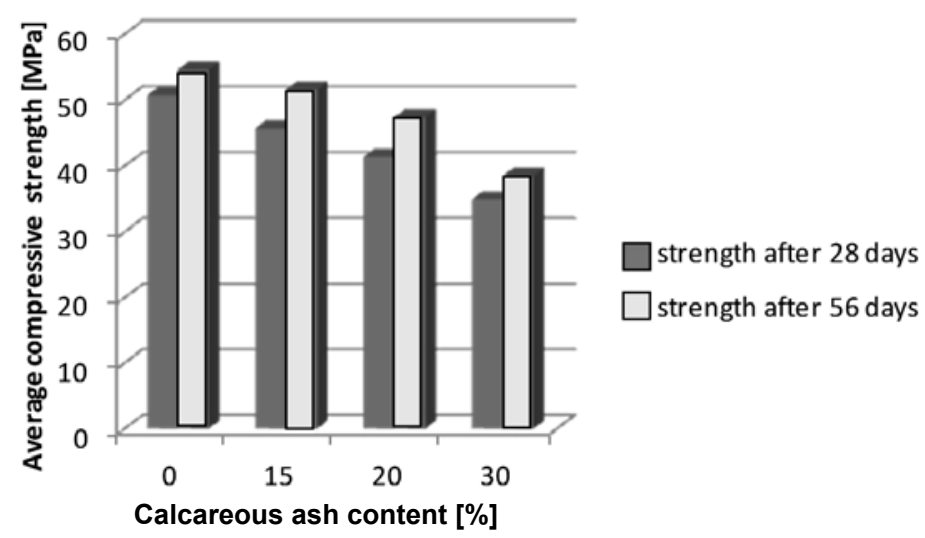

FIGURE 7. The average strength of concrete with calcareous ash after 28 and 56 days

from the production of the samples, next measurements were performed and they showed that the strength increased.

The concrete samples with the $15 \%$ of siliceous ash content proved the increase of the compressive strength from 35.6 to $44.9 \mathrm{MPa}$. For the samples with the $20 \%$ of ash content, the increase was to $40.9 \mathrm{MPa}$ and for the samples with the $30 \%$ of ash content - to $37.2 \mathrm{MPa}$. The values for the calcareous ash concretes, for both cases - after 28 and 56 days of curing, were higher than for the siliceous ash concretes. The tests performed after 28 days of curing proved that the concretes with the $15 \%$ of calcareous ash content had 10.1 MPa higher compressive strength and it was equal $45.7 \mathrm{MPa}$. After 56 days of curing, however, this strength was 6.5 MPa higher than for the samples with the siliceous ash and it was equal 51.6 MPa. For the samples with the $20 \%$ of the calcareous ash content, the compressive strength was equal 41.4 $\mathrm{MPa}$ after 28 days and $47.4 \mathrm{MPa}$ after 56 days of curing. For the samples with the $30 \%$ of the calcareous ash content, the average value after 28 days was $34.9 \mathrm{MPa}$, after 56 days $-38.5 \mathrm{MPa}$ - Figure 6 and 7.

\section{Bending strength test}

Figure 8 presents the results of the bending strength tests performed for cuboid samples with the size of $100 \times 100 \times$ $\times 500 \mathrm{~mm}$. The tests were performed after 28 days of curing.

The highest value of the bending strength was reached by the samples without ash admixtures. The values obtained for all of the samples felt into the range 3.6-5.1 MPa. The same average values were reached by the samples with the 15 and $20 \%$ of siliceous ash content. The lowest value was reached by the samples with the $30 \%$ of ash content and it was equal 3.7 MPa. The bending strength for the samples with the calcareous ash was significantly higher than this for the samples with the siliceous ash 


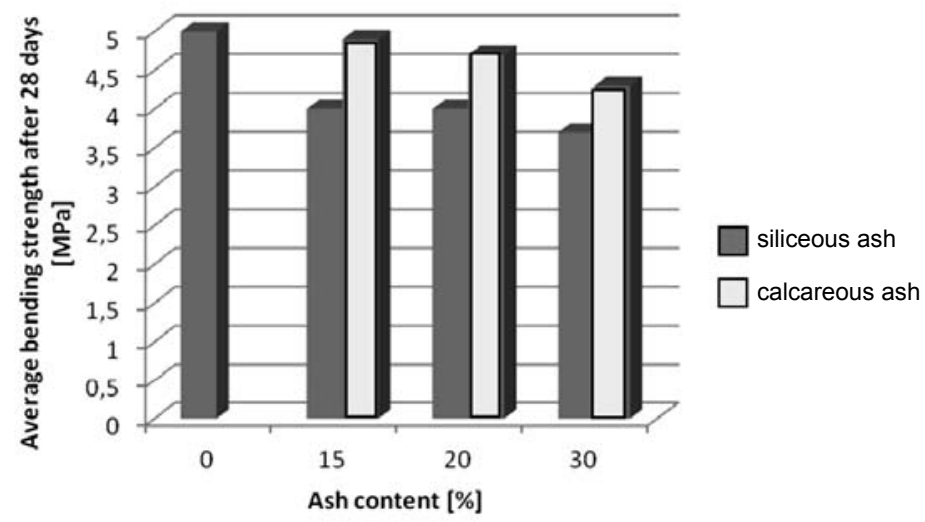

FIGURE 8. The average bending strength

and it reached the values close to those for the pure concrete. The values were equal 4.9 MPa for the $15 \%$ of ash content, $4.7 \mathrm{MPa}$ for the $20 \%$ of ash content, 4.3 $\mathrm{MPa}$ for the $30 \%$ of ash content.

\section{Splitting tensile strength test}

Figure 9 presents the splitting tensile test results for the concrete samples with the size of $150 \times 150 \times 150 \mathrm{~mm}$. The tests were performed after 28 days of curing.
The highest splitting tensile strength was reached by the samples without ash admixtures. The strength values for the samples with addition of ashes felt into the range 7,7-9,3 MPa. The samples with the $15 \%$ of siliceous ash content reached the average value of this strength equal 8.6 MPa. The 0.1 MPa lower strength was reached by the concrete with the $20 \%$ of siliceous ash content, however for the samples with the $30 \%$ of siliceous ash content this value is equal $8.3 \mathrm{MPa}$.

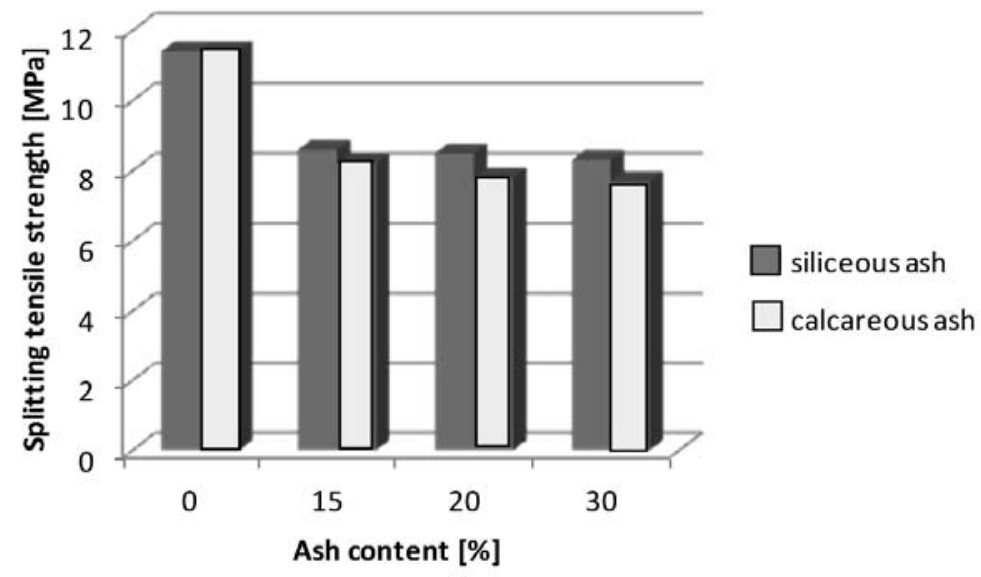

FIGURE 9. The average splitting tensile strength 
The splitting tensile strength values for the concretes with the admixture of calcareous ash were lower than those for the concretes with the siliceous ash and were equal 8.2, 7.8, and 7.7 MPa for the $15,20 \%$ and $30 \%$ of calcareous ash content, respectively.

\section{Depth of penetration of water under pressure}

Figure 10 presents the results of the tests of average depth of penetration of water under pressure in the unmodified concrete as well as in the concretes with various contents of siliceous and calcareous ash. ash content reached the value of $1.96 \mathrm{~cm}$, whereas the samples with the $30 \%$ of siliceous ash content $-1.72 \mathrm{~cm}$. For the samples with the calcareous ash, the values were equal 1.68 and $1.49 \mathrm{~cm}$ for the 15 and $30 \%$ content, respectively.

\section{Absorbability}

Figure 11 presents the results of the absorbability tests. The highest absorbability characterized the concrete samples with the admixture of calcareous ash. The percentage mass loss was equal $5.5 \%$ for the samples with the 20 and $30 \%$ of calcareous ash content as well as $5.4 \%$ for the samples with the $15 \%$

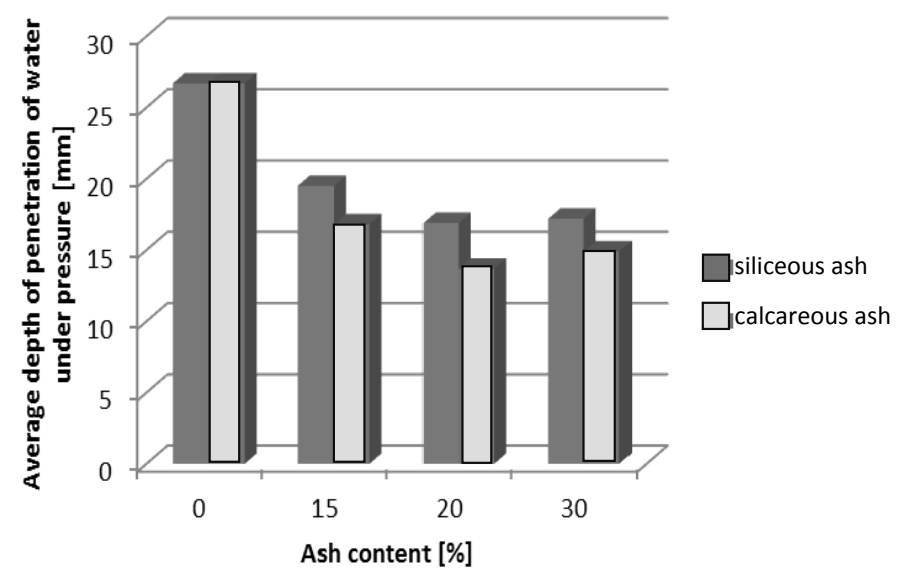

FIGURE 10. The results of tests of depth of penetration of water under pressure

The highest depth of penetration of water under pressure characterized the concrete without ash admixtures - it was equal $2.67 \mathrm{~cm}$ into the sample. The lowest value characterized the samples with the $20 \%$ of siliceous and calcareous ash content -1.69 and $1.37 \mathrm{~cm}$, respectively. The samples with the $15 \%$ of siliceous content of this ash. The ordinary concrete was characterized by the average absorbability equal $4.9 \%$, however for the $15 \%$ of siliceous ash content, the value was equal $5.1 \%$. The lowest percentage mass loss was observed for the concrete with 20 and $30 \%$ of siliceous ash content and it was equal $4.8 \%$. 


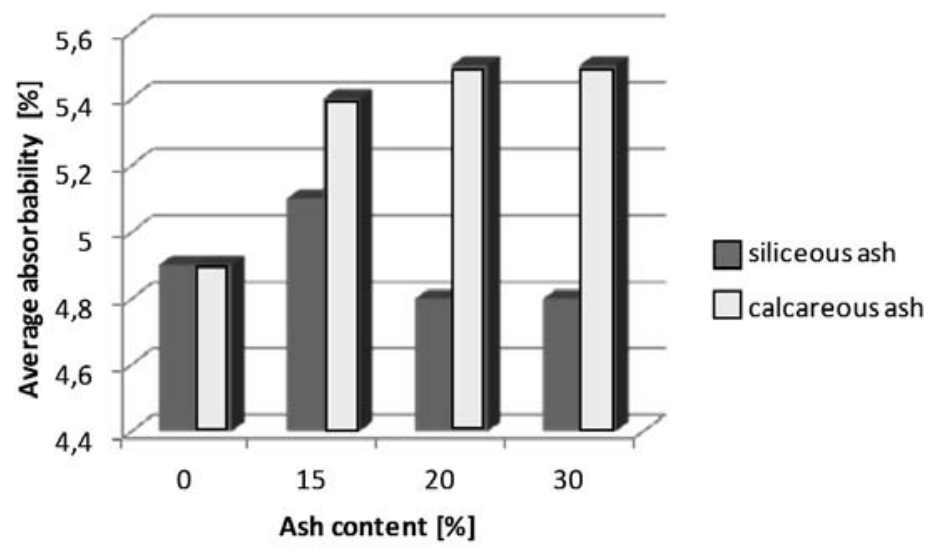

FIGURE 11 . The average absorbability of the concretes

\section{DISCUSSION}

The tests of seven concrete mixes and seven samples of hardened concrete containing the admixture of siliceous and calcareous ash in quantity of 15,20 and $30 \%$ of binder mass were performed.

The influence of ashes was evaluated on the basis of the results of the tests performed for the concrete mixes (density, consistence and air content tests) as well as for the hardened concrete (tests of compression strength after 28 and 56 days of concrete curing, bending strength, splitting tensile strength, absorbability and depth of penetration of water under pressure).

The ash admixture had smaller or greater influence on each of the tested features. The concrete mix density slightly changed its values, precisely the mix reduced its volume along with the increase of the ash quantity. Along with the increase of the ash content, the air content in the concrete mix increased.
The consistence was tested with two methods - concrete slump test and Vebe test. The concrete slump test gave the same consistence class, S1, whereas the Vebe test showed the change of the consistence class from V3 to V2 in two cases: it was observed for the mix with the 20 and $30 \%$ of calcareous ash content.

The compressive strength tests showed that the increasing ash content negatively affects the strength - the higher ash content the lower compressive strength. In the compressive strength tests performed after 28 and 56 days, the strength increase was observed along with the concrete curing time for all of the samples. The strength of the concretes with the siliceous ash admixture was lower than of the concretes with the calcareous ash admixture. For every case the obtained values were higher than those assumed during the mix calculations.

The bending strength for the concretes without admixtures also reached the highest values. Along with the ash con- 
tent increase the values of this strength decreased. The bending strength of the samples with calcareous ash was significantly higher than this of the samples with the siliceous ash admixture and almost equal to this of the samples without admixtures.

The splitting tensile strength tests were performed as well. The samples without admixtures were characterized by significantly higher value of this strength. The ash admixture negatively affected the obtained results. The results for the samples with the siliceous ash admixture were close to each other as well as higher than for those with the calcareous ash admixture.

The concrete absorbability tests showed that in every case the concrete can be directly exposed to the influence of atmospheric conditions because the absorbability value exceeded $4 \%$. The highest values were reached by the concretes with the 20 and $30 \%$ of calcareous ash content, slightly lower was the value for the concrete with the $15 \%$ of calcareous ash content. For the concretes without admixtures and with the siliceous ash, the obtained results were significantly lower.

The results of the tests of the average depth of penetration of water under pressure grade the concretes as a waterproof for each case; the value for the concretes without admixtures was the highest and equal $2.67 \mathrm{~cm}$. Along with the increase of the ash content these values slightly decreased and the lowest one was obtained for the samples with the $20 \%$ of calcareous ash content.

\section{SUMMARY AND CONCLUSIONS}

The application of mineral admixtures in cement production is currently a common action which is aimed on two aspects: ecological and technological. The direct effect of the application of admixtures is the possibility of recycling of recyclable wastes from the power and smelting industry and the production of cement with defined features which are expected in the building practice. Basing on the performed tests, the following conclusions can be put forward:

1. The admixture of siliceous and calcareous fly-ash results in the increase of air content in a concrete mix.

2. The influence of the ash admixtures on the consistence of a concrete mix has not been established.

3. The compressive strength increase for the concretes with the calcareous fly-ash admixture in comparison with the concretes with the siliceous fly-ash was observed.

4. It was established that along with the concrete curing time the compressive strength of the concretes with the siliceous and calcareous ash increases. However, it does not exceed the values for the unmodified concrete.

5. Basing on the bending strength tests, it was established that the highest value of this strength was reached by the concrete with the $15 \%$ of calcareous ash content.

6. It was observed that from among the fly-ash admixtures being applied the siliceous ash admixture gives the 
higher value of the splitting tensile strength but it is lower than this for the concrete without admixtures.

The application of fly-ashes extends the scope of mineral admixtures being possible in cement production. The ash quality, in this case calcareous ash, can affect the obtained results - according to the obtained information these ashes are characterized by a high water demand and a high contain of coarse grains having a significant porosity. The introduction of fly-ashes in building construction has a big economic and ecological value because optimizes the cement consumption, allows to apply combustion by-products, saves natural and non-renewable raw material resources and reduces the emission of $\mathrm{CO}_{2}$.

\section{REFERENCES}

ACI Committee 232, Use of fly ash in concrete. ACI committee report 232. 2R-96. ACI, April 1996.

ALONSO J.L., WESCHE K. 1991: Characterization of fly ash. Fly ash in concrete properties and performance. Report of technical committee 67-FAB-use fly ash in building (K. Wesche Ed.). RILEM, E\&FN SPON.

COMÕES A. 2002: High performance concrete incorporating fly ash. $\mathrm{PhD}$ thesis, University of Minnho.

DEJA J., ANTOSIAK B. 2012: Degree of progress of the fly ash reaction in alkali-activated fly-ash binders. Cement Wapno Beton, marzec-kwiecień.

Investigation report 721/2014.

GIERGICZNY Z. 2006: Rola popiołów lotnych wapiennych i krzemionkowych w kształtowaniu właściwości współczesnych spoiw budowlanych i tworzyw cementowych [Role of calcareous and siliceous fly-ashes in creation of properties of modern building binders and cement materials]. Wydawnictwo Politechniki Krakowskiej, Kraków (in Polish).

GIERGICZNY Z. 2013: Popiół lotny w składzie cementu $\mathrm{i}$ betonu [Fly-ashes in composition of cement and concrete]. Wydawnictwo Politechniki Śląskiej, Gliwice (in Polish).

GOLEC T., REMISZEWSKI K., ŚWIĄTKOWSKI B., BŁESZNOWSKI M. 2007: Palniki pyłowe na biomasę [Biomass powdered-fuel burners]. Energetyka i Ekologia 5, 375-382 (Engl. abstract).

GUPTA S.M. 2007: Support vector machines based modelling of concrete strength. Engineering and Technology, World Academy of Science.

JAMROŻY Z. 2005: Beton i jego technologie [Concrete and its technologies]. Wydawnictwo Naukowe PWN (in Polish).

JOSHI R.C., LOHTIA R.P. 1997: Fly ash in concrete: production properties and uses. In: V.M. Malhot (Ed.). Advances and Concrete Technology. Vol. 2. Gordon and Breach Science Publishers, Ottawa Ontario, Canada.

KIM J.I., KIM D.K. 2002: Application of neural networks for estimation of concrete strength. KSCE Journal of Civil Engineering 6, 4, 429-438.

KODA E., OSIŃSKI P. 2011: Slope erosion control with the use of fly-ash and sewage sludge. Annals of Warsaw University of Life Sciences - SGGW, Land Reclamation 43 (2), 101-111.

LAI S., SERRA M. 1997: Concrete strength prediction by means of neural network. Construction and Building Materials 11, 2, 93-98.

MALHOTRA V.M., RAMEZANIANPOUR A.A. 1994: Fly ash in concrete. 2nd edn. CANMT - Canada Centre for Mineral and Energy Technology.

MARTINS F.F., CAMÕES A. 2013: Prediction of compressive strength of concrete containing fly ash using data mining techniques. Cement Wapno Beton, styczeń - luty (Engl. abstract).

PN-EN 197-1:2002. Cement. Część 1. Skład, wymagania i kryteria zgodności dotyczące cementów powszechnego użytku [Cement. Part 1. Composition, specifications and conformity criteria for common cements]. 
PN-EN 12350-2:2001. Badania mieszanki betonowej. Część 2. Badanie konsystencji metodą opadu stożka [Testing of fresh concrete. Part 2. Slump test].

PN-EN 12390-3:2011. Badania betonu. Część 3. Wytrzymałość na ściskanie próbek do badań [Testing of hardened concrete.- Part 3. Compressive strength of test specimens].

PN-EN 12390-5:2011. „Badania betonu. Część 5. Wytrzymałość na zginanie próbek do badań [Testing of hardened concrete. Part 5. Bending strength of test specimens].

PN-EN 12390-6:2011. Badania betonu. Część 6. Wytrzymałość na rozciąganie przy rozłupywaniu próbek do badań [Testing of hardened concrete. Part 6. Splitting tensile strength of test specimens].

PN-EN 206-1:2003. Beton. Część 1. Wymagania, właściwości, produkcja i zgodność [Concrete. Part 1. Requirements, Properties, Manufacturing and Conformity].

PN-EN 450-1+A1:2009. Popiół lotny do betonu. Część 1. Definicje, specyfikacje i kryteria zgodności [Fly-ashes for concrete. Part 1: Definitions, specifications and conformity criteria].

PN-EN 450-2. Popiół lotny do betonu. Część 2. Ocena zgodności [Fly-ashes for concrete. Part 1. Evaluation of conformity].

PN-88/B-06250. Beton zwykły [Ordinary concrete].

ROSIK-DULEWSKA CZ., KARWACZYŃSKA U. 2008: Metody ługowania zanieczyszczeń z odpadów mineralnych w aspekcie możliwości ich zastosowania w budownictwie hydrotechnicznym [Methods of leaching of impurities in mineral waste from the point of view of its application in hydrotechnical engineering]. Rocznik Ochrony Środowiska 10, 205-218. (Engl. abstract).

RUTKOWSKA G., MAŁUSZYŃSKA I. 2014: Badania właściwości betonu wyprodukowanego $\mathrm{z}$ dodatkiem popiołu lotnego [Investigations of properties of concrete produced with admixtures of fly-ashes]. Inżynieria Ekologiczna 36, 53-64 (Engl. abstract).
WESCHE K. 1991: Fly ash in concrete; properties and performance. Report of technical committee 67-FAB-use of fly ash in building (K. Wesche Ed.). RILEM, E\&FN SPON.

Streszczenie: Wplyw popiołów lotnych na właściwości betonów zwyklych. Dbałość o środowisko zgodnie z zasadami zrównoważonego rozwoju wprowadza możliwości i potrzebę stosowania recyklingu odpadów. Najważniejsze możliwości ponownego zagospodarowania popiołów lotnych ma sektor budowlany - branża materiały budowlane. $\mathrm{W}$ artykule przedstawiono wyniki badań właściwości (konsystencji, nasiąkliwości, wytrzymałości na ściskanie, zginanie po 28 , 56 dniach dojrzewania, głębokość penetracji) betonów zwykłych oraz betonów zawierających w swoim składzie lotny-krzemionkowy i wapienny popiół. Do wykonania betonu użyto cement portlandzki CEM I 42,5 R, kruszywo naturalne 0-16 mm. Beton z dodatkiem popiołu krzemionkowego i wapiennego wykonano w trzech partiach, gdzie popiół dodawano w ilości 15, 20, $30 \%$ masy cementu. Po wykonaniu badań stwierdzono, że dodatek popiołu lotnego nie zwiększa zawartości powietrza w mieszance, zwiększa wytrzymałość na ściskanie w czasie, z kolei popiół krzemionkowy poprawia wytrzymałość na rozciąganie przy rozłupywaniu.

Stowa kluczowe: odpady przemysłowe, popiół lotny, beton zwykły, beton z dodatkiem

\section{MS. received February 2016}

\section{Authors' address:}

Gabriela Rutkowska, Krzysztof Wiśniewski, Marek Chalecki

Wydział Budownictwa i Inżynierii Środowiska SGGW

Katedra Inżynierii Budowlanej

ul. Nowoursynowska 159, 02-776 Warszawa

Poland

e-mail: gabriela_rutkowska@sggw.pl krzysztof_wisniewski@sggw.pl marek_chalecki@sggw.pl 